\title{
FAKTOR - FAKTOR YANG MEMPENGARUH MANAJEMEN ASSET PADA PEMERINTAH KOTA LHOKSEUMAWE
}

\author{
Oleh \\ Yusnidar $^{1}$, Muammar Khadafi ${ }^{2 *}$, Damanhur ${ }^{3}$ \\ ${ }^{123}$ Pascasarjana Ilmu Manajemen Fakultas Ekonomi dan Bisnis Universitas Malikussaleh \\ Email: yusnidar171100410093@mhs.unimal.ac.id ${ }^{1}$,khaddafi@unimal.ac.id ${ }^{2}$, damanhur@unimal.ac.id ${ }^{3}$
}

\section{ABSTRACT}

This study aims to examine the Factors Affecting Asset Management in Lhokseumawe City Government. The data used in this study are primary data of 102 respondents. Data analysis method in this research uses structural equation model with the help of analysis of moment structure. The results showed that, regional apparatus, regulations, accounting information systems and organizational commitment had a positive and significant effect on asset management in the Lhokseumawe City Government. While accountability does not affect asset management in the Lhokseumawe City Government.

Keywords : Quality of Regional Apparatus, Regulation, Accountability, Accounting Information Systems, Organizational Commitment and Asset Management

\section{Pendahuluan}

Diberlakukannya kebijakan nasional mengenai pelaksanaan otonomi daerah menyebabkan setiap daerah memiliki kewenangan yang lebih luas dalam mengelola daerahnya. Peraturan tersebut telah di tuangkan dalam undang-undang nomor 22 Tahun 1999 dan undang-undang nomor 32 tahun 2004 yang selanjutnya direvisi dengan undang-undang nomor 23 tahun 2004 dan direvisi kembali menjadi undang-undang nomor 24 tahun 2015 tentang pemerintah daerah. Berawal dari adanya undang-undang tersebut maka pemerintah di tuntut untuk dapat dengan baik mengelola setiap kekayaan daerah guna untuk menunjang pembangunan suatu daerah baik baik kabupaten maupun Kota.

Regulasi - regulasi di atas menunjukkan bahwa posisi aset pemerintah daerah sangatlah penting dalam pengelolaan keuangan Negara. Dalam pasad 1 angka 2 PP No.27/2014 menjelaskan bahwa barang milik daerah adalah semua barang yang dibeli ataupun diperoleh atas beban anggaran pendapatan dan belanja daerah atau berasal dari perolehan lainnya yang sah. Maka pemerintah daerah dituntut harus lebih efektif dan efisien dalam mengelola manajemen aset daerah

Untuk meningkatkan dukungan pengelolaan aset daerah secara efesien, efektif dan menguntungkand iperlukan adanya sinergisitas serta menciptakan transparansi kebijakan manajemen/pengelolaan aset daerah sehingga pemerintah daerah perlu menerapkan sistem pengawasan sebagai alat untuk mengawasi jalannya manajemen aset Pemerintah Daerah. Kelemahan pengawasan dari pihak internal akan menyebabkan pengelolaan aset tidak berjalan efektif dan efisien. Terkait pengelolaan barang Milik daerah telah di atur dalam Standar Akuntansi Pemerintahan Tahun 2010.

Pengelolaan aset milik pemerintah daerah masih dalam kondisi yang memprihatinkan, secara umum banyak pejabat dan kualitas aparatur daerah belum mengelola aset secara efektif, efesien. Permasalah tersebut dijumpai pada kelemahan yang terdapat pada fisik barang dimana sebagian besar fisik barang tidak bisa langsung diidentifikasi karena tidak diberi nomor register barang atau nomor register yang menempel pada fisiknya. Nomor register merupakan bagian dari kodefikasi aset daerah yang memuat nomor urut pencatatan dari setiap barang, pencatatan terhadap 
barang yang sejenis, dan tahun pengadaan barang. Kondisi ini juga berdampak pada kehilangan barang milik daerah tanpa alasan yang jelas disebabkan karena lemahnya aspek penanganan. Adanya kejadian kejadian yang merugikan pihak pemerintah daerah dan juga masyarakat maka dalam hal ini pengawasan manajemen aset yang lebih baik sangat dibutuhkan khususnya di pemerintah Kota Lhokseumawe.

Permasalah yang terjadi dengan pengelolaan aset tetap yaitu pemerintah Kota Lhokseumawe hingga saat ini belum memfungsikan Pasar Induk (Terpadu) yang dibangun di Jalan Lingkar, Desa Ujong Blang, Kecamatan Banda Sakti, Lhokseumawe. Empat bangunan dalam Komplek Pasar Induk yang di bangun secara bertahap sejak tahun 2015 hingga 2018 dengan menghabiskan dana mencapai Rp13 miliar terkesan terbengkalai karena tidak difungsikan. Bahkan, kondisi dalam komplek pasar sudah dipenuhi ilalang panjang dan sebahagian kaca jendela bangunan tampak sudah banyak yang pecah dan rusak.

Kelemahan dalam pengelolaan aset tersebut diduga berkaitan dengan kinerja aparatur pengelola aset dimana terdapat unsur ketidakcermatan dari pengelola aset dalam melakukan penatausahaan. Kondisi pada saat pemeriksaan dapat dikatakan bahwa kinerja pengelola yang tidak teliti dan kurangnya kehati-hatian dalam melakukan tugas sebagai pengelola aset.

Pengelolaan Manajemen aset tidak terlepas dari kinerja kualitas aparatur daerah, Regulasi, Akuntabilitas, sistem informasi akuntansi akuntansi dan komitmen organisasi organisasi. Dengan berlakunya UU No.32/2004 tentang Pemerintahan Daerah, dimana setiap daerah berwenang mengatur dan mengurus sendiri rumah tangga daerahnya masing-masing, maka dibutuhkan kualitas aparatur daerah yang handal untuk menjamin penyelenggaraan tugas pemerintahan dan pembangunan secara berdayaguna dan berhasilguna. Oleh karena itu kualitas kualitas aparatur daerah sangat berperan penting dalam pengelolaan aset untuk suatu organisasi atau lembaga pemerintahan.

Dalam melaksanakan tugasnya pejabat pengurus dan penyimpan barang, dituntut untuk memiliki kapabilitas atau kompetensi yang dinilai dari latar belakang pendidikan, pengalaman, dan pelatihan/bimbingan teknis yang pernah diikutinya yang sesuai dengan jabatannya. Selain kualitas kualitas aparatur daerah, perlu dilihat juga apakah sudah efektif regulasi pada Pemerintahan Kota Lhokseumawe sebagai dasar untuk pejabat tersebut mengelola aset tetap daerah.

Hasil riset yang dilakukan oleh Rosihan et all (2014) menunjukkan bahwa kualitas kualitas aparatur daerah berpengaruh positif dan signifikan terhadap manajemen aset Pemerintah Provinsi Papua, sama halnya dengan hasil riset yang dilakukan Iqlima (2014) menunjukkan bahwa kualitas kualitas aparatur daerah berpengaruh positif dan signifikan terhadap manajemen aset pada SKPD di Pemko Banda Aceh. Serta hasil riset Arlini et all (2014) menunjukkan bahwa kualitas kualitas aparatur daerah berpengaruh positif dan signifikan terhadap manajemen aset pada Satuan Kerja Badan Kependudukan Dan Keluarga Berencana Nasional Di Indonesia.

Faktor lain dari pengelolaan manajemen aset juga dapat dilihat dari regulasi. Regulasi, kebijakan, dan prosedur sangatlah penting dalam pengelolaan daerah sebagai pedoman yang merupakan prinsip kerja dan petunjuk secara luas maupun spesifik tentang bagaimana aktiva tetap seharusnya dikelola, Oleh karena itu, regulasi diduga berpengaruh terhadap manajemen aset.

Hasil riset yang dilakukan oleh Rosihan et all (2014) menunjukkan bahwa regulasi berpengaruh positif dan signifikan terhadap manajemen aset Pemerintah Provinsi Papua. Hasil riset Azhar (2017), Arlini et all (2014), Mainar et all (2017) serat Azhar et all (2013) juga menunjukkan bahwa regulasi berpengaruh positif dan signifikan terhadap manajemen aset.

Adapun akuntabilitas publik merupakan landasan bagi proses penyelenggara pemerintah yang baik (Good Governance), Aparatur pemerintah harus mempertanggung jawabkan tindakan dan pekerjaannya pertama kepada publik dan kedua kepada organisasi tempat kerjanya. Dengan akuntabilitas publik setiap aparatur harus mampu dapat menyajikan informasi yang benar dan lengkap untuk memilai kinerjanya baik yang dilakukan oleh masyarakat, organisasi / instansi kerjanya, dan kelompok.

Hasil riset yang dilakukan oleh Bustamam dan Yuliani (2017) menunjukkan bahwa akuntabilitas berpengaruh positif dan signifikan terhadap manajemen aset Kota Banda Aceh. Hal 
ini juga ditunjukkan oleh hasil riset yang dilakukan Muljo et all (2014) serta Handriant (2014) bahwa akuntabilitas berpengaruh positif dan signifikan terhadap manajemen aset.

Faktor lain yang juga relatif mempunyai kontribusi terhadap pengaruh manajemen aset adalah Sistem informasi akuntansi Pengelolaan Keuangan Daerah. Sistem informasi akuntansi sebagai salah satu upaya yang diperlukan untuk mengelola aset daerah juga dianggap penting, sesuai dengan PP No.56/2005 tentang Sistem informasi akuntansi Keuangan Daerah. dalam penelitian ini sistem informasi akuntansi yang akan dibahas difokuskan pada sistem informasi akuntansi akuntansi.

Sistem informasi akuntansi Akuntansi dalam Sistem Perencanaan dan Pengendalian Sektor Publik mempunyai arti dan peran penting terkait pada fungsinya dalam pengukuran dan pengendalian. Sistem akuntansi yang dirancang secara baik, akan menjamin dilakukannya prinsip stewardship dan accountability dengan baik pula (Jones, dalam Afiah, 2009). Pernyataan ini sejalan dengan riset yang dilakukan Budiono (2014). Hasil riset yang dilakukan Azhar (2017) menunjukkan bahwa sistem informasi akuntansi berpengaruh positif dan signifikan terhadap manajemen aset di Kota Banda Aceh.

Selain faktor-faktor yang telah diulas diatas, faktor komitmen organisasi juga berpotensi mempengaruhi pengelolaan aset daerah, khususnya komitmen organisasi yang bersumber dari pimpinan. Hal ini ditandai dengan adanya informasi-informasi yang diperoleh menunjukkan bahwa pimpinan yang tidak memperhatikan masalah aset membuat pengelolaan aset ini menjadi persoalan rumit (Simamora dan Halim, (2012).

Pimpinan yang memahami kompleksitas atau keanekaragaman kemampuan, sikap, serta perilakudari personel organisasi akan dapat menjalankan strateginya dalam mempengaruhi bawahannya.

Pernyataan diatas juga didukung oleh hasil-hasil kajian empiris diantaranya adalah Simamora dan Halim, (2012) yang menyatakan bahwa salah satu faktor yang mempengaruhi pengelolaan aset pasca pemekaran wilayah di Kabupaten Tapanuli Selatan sebagai daerah induk dan Kabupaten Padang Lawas Utara, Kabupaten Padang Lawas dan Kota Padang Sidimpuan sebagai daerah pemekaran adalah komitmen organisasi pimpinan. Sejalan dengan hasil tersebut, Mulyanto (2010) dan Rachmawati (2010) juga menyatakan bahwa komitmen organisasi pimpinan berpengaruh signifikan terhadap kinerja.

Berdasarkan uraian latar belakang dan hasil penelitian terdahulu, maka penulis tertarik untuk melaksanakan penelitian ini dengan judul "Manajemen Aset Daerah Pemerintah Kota Lhokseumawe dan Faktor-Faktor Yang Mempengaruhinya"

\section{KAJIAN PUSTAKA}

\section{Kualitas Aparatur Daerah}

Sumber daya manusia atau pada pemerintahan daerah biasanya disebut aparatur daerah harus mempunyai kualitas yang memadai sehingga dapat melaksanakan tugas dan fungsinya dangan baik. Terkait dengan kualitas atau kemampuan SDM, Robbins (2015) mendefinisikan kemampuan merujuk ke kapasitas individu untuk mengerjakan berbagai tugas dalam pekerjaan tertentu. Kemampuan keseluruhan seseorang pada hakikatnya tersusun dari dua faktor yaitu kemampuan intelektual dan kemampuan fisik. Menurut Siregar (2016), sumber daya manusia adalah semua potensi yang terdapat pada manusia, seperti akal pikiran, seni, keterampilan, dan sebagainya yang dapat digunakan untuk memenuhi kebutuhan bagi dirinya sendiri maupun orang lain atau masyarakat pada umumnya.

\section{Regulasi}

Peraturan adalah ketentuan yang digunakan untuk mengatur hubungan antar manusia dalam sebuah masyarakat dan atau sebuah negara (Kurniawan, 2015). Regulasi menurut Kamus Besar Bahasa Indonesia adalah pengaturan. Regulasi di Indonesia diartikan sebagai sumber hukum formil berupa peraturan perundang-undangan yang memiliki beberapa unsur, yaitu merupakan 
suatu keputusan yang tertulis, dibentuk oleh lembaga negara atau pejabat yang berwenang, dan mengikat umum. Untuk mendukung penyelenggaraan Negara agar berjalan dengan lancar, maka dibuatlah peraturan perundang-undangan untuk kepentingan masyarakat. Peraturan tersebut juga mengatur penyelenggaraan Negara (pemerintah), artinya setiap pemerintah dan penyelenggara negara dibatasi oleh peraturan perundang-undangan, atau dengan kata lain pemerintah tidak boleh berkuasa mutlak, tanpa batas.

\section{Akuntabilitas}

Menurut Triyuwono yang dikutip oleh Permatasari dan Dewi (2017) menyatakan bahwa ruang lingkup akuntabilitas dalam akuntansi Islam meliputi empat jenis akuntabilitas salah satunya yaitu akuntabilitas kepada Tuhan atau pertanggungjawaban kepada Tuhan. Menurut Bappenas (2014) definisi akuntabilitas adalah alat untuk menjawab dan menerangkan kinerja dan tindakan seseorang/pimpinan organisasi kepada pihak yang memiliki hak atau kewenangan untuk meminta pertanggungjawaban atau keterangan.

\section{Sistem Informasi Akuntansi}

Teknologi informasi digunakan dalam manajemen aset untuk menghasilkan gambaran informasi siklus aset yang terintegrasi, tidak hanya menjadi pengawasan terhadap manajemen aset, tetapi juga memungkinkan untuk mendukung informasi dalam pengambilan keputusan (Haider, 2011). Menurut Hall (2011), Sistem informasi akuntansi adalah susunan berbagai macam formulir catatan, peralatan termasuk komputer dan perlengkapnya, dokumentasi alat komunikasi, tenaga pelaksana, dan berbagai laporan yang didesain untuk mentransformasikan data keuangan menjadi informasi yang dibutuhkan manajemen.

\section{Komitmen Organisasi}

Mathus dan Jackson (2012) merumuskan bahwa komitmen organisasi merupakan tingkat kepercayaan dan peneriman pekerja terhadap tujuan organisasi dan mempunyai keinginan untuk tetap ada dalam organisasi tersebut yang pada akhirnya tergambar dalam statistik kehadiran dan masuk keluarnya pekerja dari organisasi (turnover). Sedangkan menurut Robbins (2015), komitmen pegawai pada suatu organisasi adalah suatu keadaan di mana karyawan memihak kepada organisasi tertentu dan tujuan-tujuannya, serta berniat memelihara keanggotaannya dalam organisasi itu.

\section{Manajemen Aset}

Manajemen adalah alat untuk mencapai tujuan yang diinginkan, manajemen yang baik akan memudahkan terwujudnya tujuan perusahaan, karyawan, dan masyarakat. Pengertian manajemen itu sendiri adalah ilmu dan seni mengatur proses pemanfaatan sumber daya manusia dan sumber-sumber lainnya secara efektif dan efisien untuk mencapai suatu tujuan tertentu (Hasibuan, 2017). Manajemen menurut kamus besar bahasa Indonesia (KBBI), adalah "penggunaan sumber daya secara efektif untuk mencapai sasaran" atau pimpinan yang bertanggungjawab atas jalannya perusahaan dan organisasi.

\section{KERANGKA KONSEPTUAL}

Kerangka konseptual penelitian menurut Handoko dan Iskandar (2008) menjelaskan secara teoritis model kensepyual variabel-variabel penelitian,

Berdasarkan teori dan penelitian terdahulu pada halaman sebelumnya pennelitian ini bertujuan untuk melihat pengaruh manajemen aset dan faktor-faktor yang mempengaruhinya 
pada Pemerintah Kota Lhokseumawe. Berikut ini adalah kerangka pemikiran dari penelitian yang dilakukan.

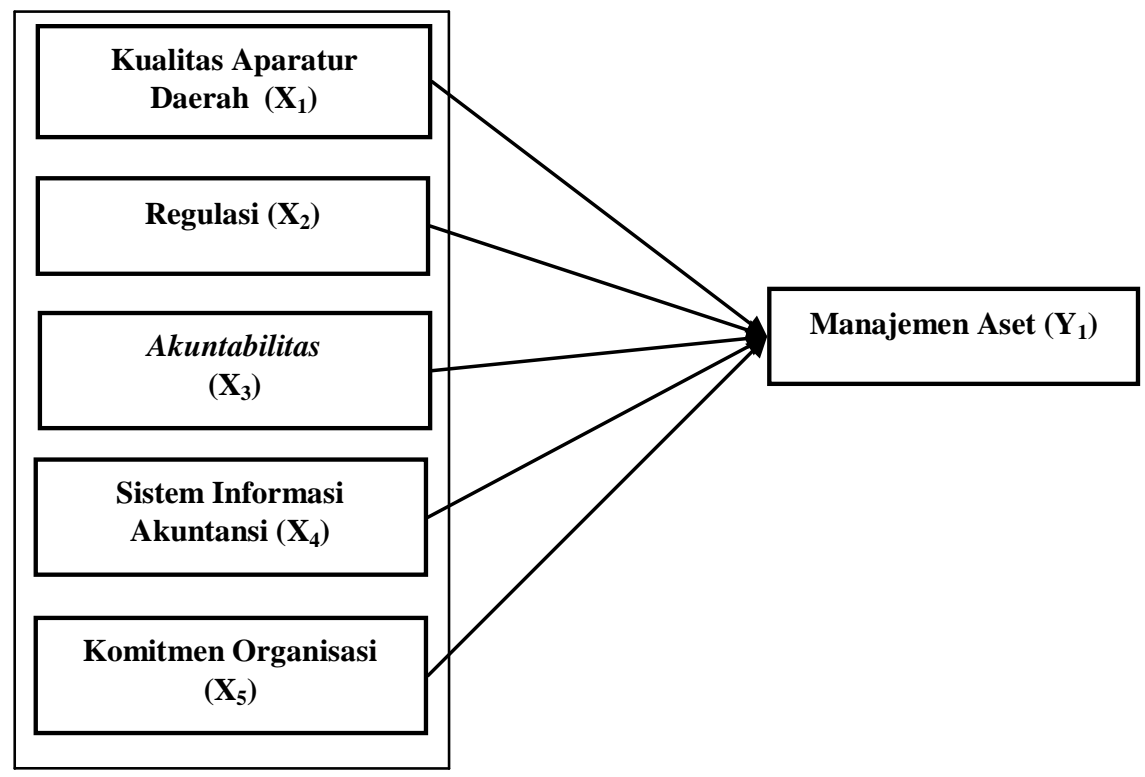

\section{Hipotesis}

\section{Gambar Kerangka Konseptual Penelitian}

Dari kerangka konseptual penelitian, dirumuskanlah hipotesis penelitian sebagai berikut:

$\mathrm{H}_{1}$ : Kualitas aparatur daerah berpengaruh manajemen aset pada Pemerintah Kota Lhokseumawe.

$\mathrm{H}_{2}$ : $\quad$ Regulasi berpengaruh manajemen aset pada Pemerintah Kota Lhokseumawe.

$\mathrm{H}_{3}$ : $\quad$ Akuntabilitas berpengaruh manajemen aset pada Pemerintah Kota Lhokseumawe.

$\mathrm{H}_{4}$ : Sistem Informasi Akuntansi berpengaruh manajemen aset pada Pemerintah Kota Lhokseumawe.

$\mathrm{H}_{5}$ : Komitmen Organisasi berpengaruh manajemen aset pada Pemerintah Kota Lhokseumawe.

\section{Metode Penelitian}

\section{Objek dan Lokasi Penelitian}

Penelitian ini dilakukan pada Pemerintah Kota Lhokseumawe. Adapun yang menjadi objek dalam penelitian ini adalah 34 Satuan Perangkat Kerja Daerah (SKPD) Kota Lhokseumawe. Ruang lingkup penelitian adalah Kualitas Aparatur Daerah, Regulasi, Akuntabilitas, Sistem Informasi Akuntansi dan Komitmen Organisasi terhadap Manajemen Aset.

\section{Populasi dan Sampel}

Populasi dalam penelitian ini 34 SKPD di Kota Lhokseumawe, yaitu sebanyak 7 (tujuh) kelompok SKPD yang terdiri dari 102 responden. Penentuan sampel dengan menggunakan metode sensus. Dengan demikian jumlah sampel penelitian ini adalah sama dengan jumlah populasi, yaitu sebanyak 102 responden.

\section{Teknik Pengumpulan Data}


Teknik pengumpulan data yang digunakan dalam penelitian ini adalah dengan menyebarkan kuesioner kepada responden penelitian dan pengukurannya dengan menggunakan Skala Likert.

\section{Pengujian Instrumen Penelitian}

Ghozali (2011) menyatakan bahwa uji kualitas data terdiri dari uji validitas dan uji reliabilitas.

\section{Uji Validitas}

Data yang valid adalah data yang tidak berbeda antara data yang dilaporkan oleh peneliti dengan data yang sesungguhnya terjadi pada objek penelitian. Dalam SEM pengujian validitas dilakukan dengan Confirmatory Factor Analysis (CFA). Suatu indikator dikatakan valid apabila nilai loading factor untuk setiap butir indikatornya lebih besar 0,60 (Ghozali, 2014).

2. Uji Reliabilitas

Pada dasarnya uji reliabilitas menunjukan sejauhmana suatu alat ukur dapat memberikan hasil yang relatif sama bila dilakukan pengukuran kembali pada subjek yang sama. Uji reliabilitas dilakukan dengan dua cara yaitu Construct Reliability (CR) dan Variance Extracted (VE). Nilai batas yang digunakan untuk menilai Construct Reliability (CR) adalah 0,70. Sedangkan nilai Variance Extracted (VE) direkomendasikan pada tingkat paling sedikit 0,50.

\section{Metode Analisis Data}

Metode analisis data yang akan digunakan dalam penelitian ini adalah Structural Equation Modelling (SEM) yang dioperasikan melalui program Analysis of Moment Structure (AMOS).

\section{Hasil Penelitian}

\section{Full Model Sebelum Modifikasi}

Full model SEM sebelum modifikasi bertujuan untuk melihat sejauhmana model dasar yang dibentuk dalam penelitian ini memenuhi kriteria goodness of fit sehingga model dapat menggambarkan fenomena penelitian tanpa adanya modifikasi. Full model SEM sebelum modifikasi ditampilkan dalam gambar berikut ini. 


\section{Gambar Full Model Sebelum Modifikasi}

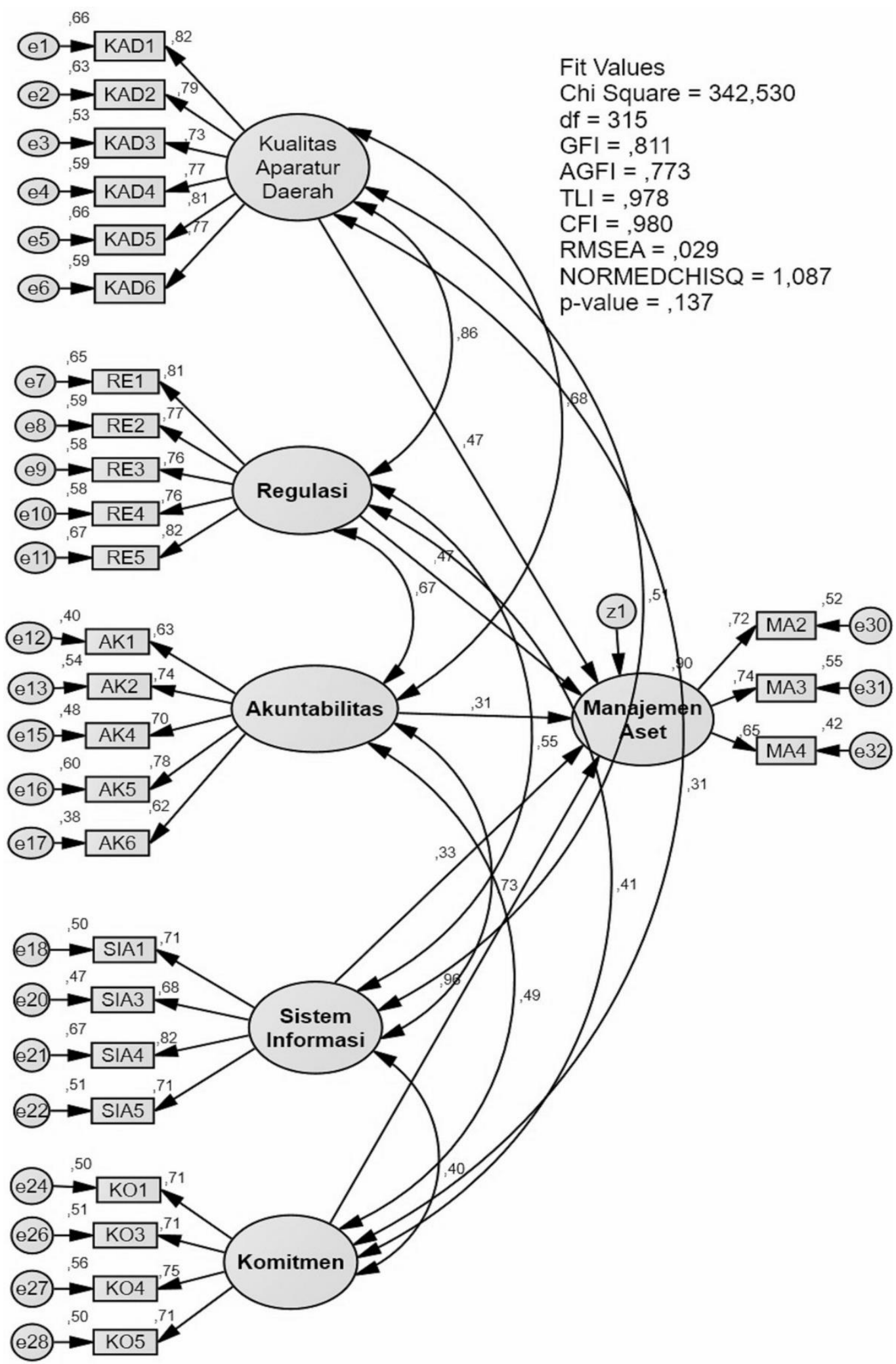

Sumber:Data Kuesioner 2020 Diolah Oleh Peneliti Dengan Program AMOS 
Berdasarkan data Gambar di atas bahwa belum seluruh nilai Goodness Of Fit (GOF) memenuhi kriteria yang ditentukan, misalnya nilai GFI masih marginal $(0,811<0,90)$ dan nilai AGFI juga masih marginal $(0,773<0,90)$. Dengan demikian model penelitian belum sesuai dan belum mampu menjelaskan model penelitian dengan tepat dan baik, sehingga model penelitian ini perlu dilakukan modifikasi. Nilai Goodness Of Fit (GOF) sebelum modifikasi dapat dilihat pada tabel di bawah ini:

Tabel Kriteria Goodness $O$ f Fit Model Sebelum Modifikasi

\begin{tabular}{clrrr}
\hline No & Goodness Of Fit Index & Cut Of Value & Hasil & Kesimpulan \\
\hline 1 & Chi-square $\left(\mathrm{X}^{2}\right)$ & Diharapkan kecil & 342,530 & Baik \\
2 & P-Value & $\geq 0,05$ & 0,137 & Baik \\
3 & CMIN/DF & $\leq 2,00$ & 1,087 & Baik \\
4 & GFI & $\geq 0,90$ & 0,811 & Marginal \\
5 & AGFI & $\geq 0,90$ & 0,773 & Marginal \\
6 & TLI & $\geq 0,95$ & 0,978 & Baik \\
7 & CFI & $\geq 0,95$ & 0,980 & Baik \\
8 & RMSEA & $\leq 0,08$ & 0,029 & Baik \\
\hline
\end{tabular}

Sumber: Data Kuesioner 2020 Diolah Oleh Peneliti Dengan Program AMOS

\section{Full Model Setelah Modifikasi}

Uji kesesuaian model setelah modifikasi dilakukan dengan cara menghubungkan antar error pada setiap indikator yang disarankan oleh sistem. Tujuannya adalah untuk menaikkan nilai goodness of fit agar model benar-benar layak dan tepat untuk menjelaskan model penelitian. Full model setelah modifikasi dapat dilihat pada gambar berikut ini.

\section{Gambar Full Model Tesis Setelah Modifikasi}

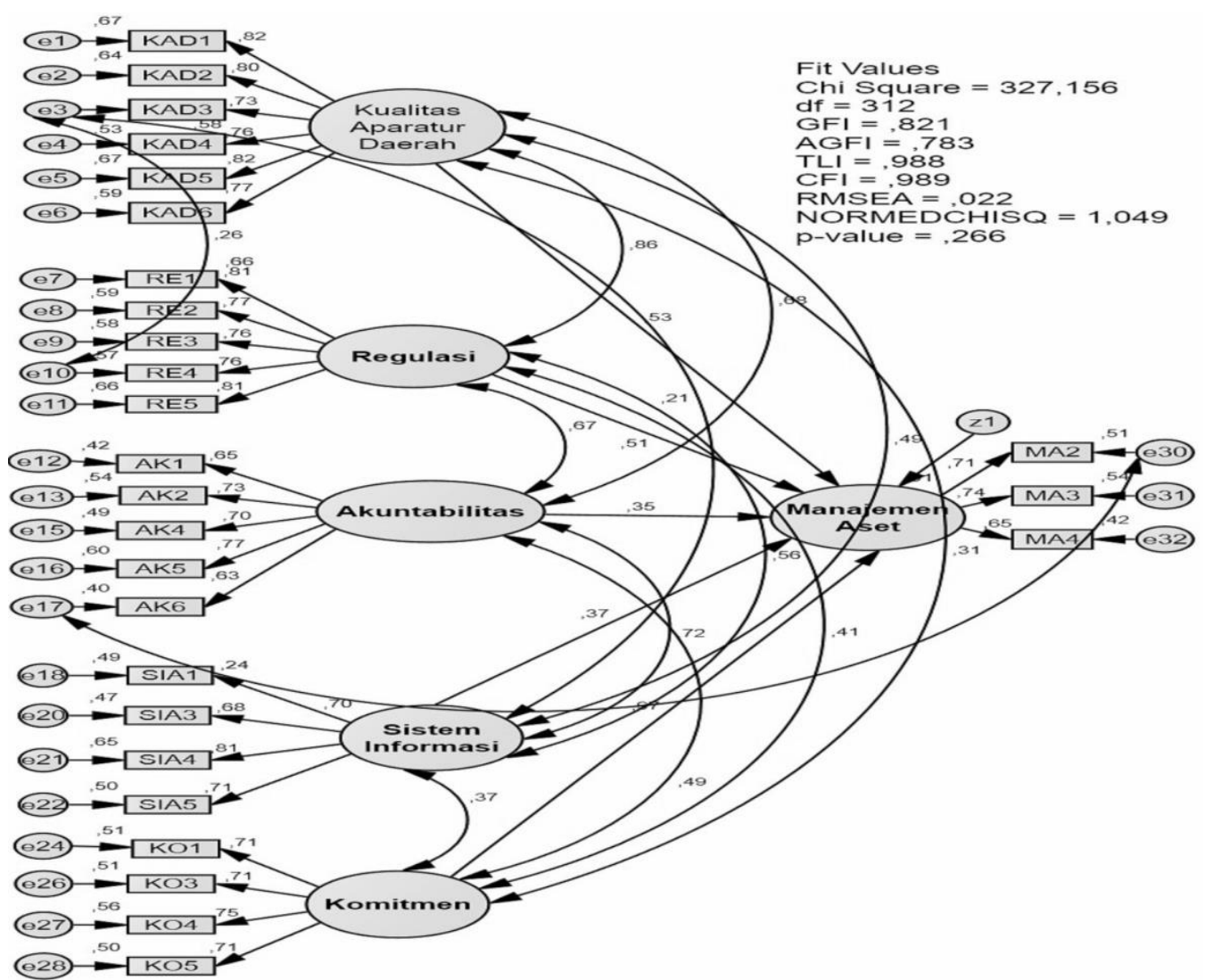


Secara umum semua konstruk yang digunakan untuk membentuk model penelitian ini setelah dimodifikasi telah memenuhi kriteria Goodness of Fit (GOF) yang telah ditetapkan seperti nilai Chi-Squareg, RMSEA, TLI, CFI, CMIN/DF dan P-Value kecuali nilai GFI masih marginal $(0,821<0,90)$ dan AGFI yang masih marginal $(0,783<0,90)$ namun sudah mendekati baik seperti yang terlihat pada tabel di bawah ini:

Tabel Kriteria Goodness Of Fit Full Model SetelahModifikasi

\begin{tabular}{|clrrr|}
\hline No & Goodness Of Fit Index & Cut Off Value & Nilai Hasil & Kesimpulan \\
\hline 1 & Chi-square $\left(\mathrm{X}^{2}\right)$ & Diharapkan kecil & 327,156 & Baik \\
2 & P-Value & $\geq 0.05$ & 0,266 & Baik \\
3 & CMIN/DF & $\leq 2.00$ & 1,049 & Baik \\
4 & GFI & $\geq 0.90$ & 0,821 & Marginal \\
5 & AGFI & $\geq 0.90$ & 0,783 & Marginal \\
6 & TLI & $\geq 0.95$ & 0,988 & Baik \\
7 & CFI & $\geq 0.95$ & 0,989 & Baik \\
8 & RMSEA & $\leq 0.08$ & 0,022 & Baik \\
\hline
\end{tabular}

Sumber: Data Kuesioner 2020 Diolah Oleh Peneliti Dengan Program AMOS

\section{Pembuktian Hipotesis}

Pembuktian keseluruhan hipotesis dapat dilakukan dengan berdasarkan nilai probabilitas dari suatu pengaruh satu variabel dengan variabel lainnya. Pembuktian keseluruhan dapat dilihat pada tabel di bawah ini, yaitu:

Pembuktian Hipotesis Regression Weight Structural Equation Model

\begin{tabular}{|c|l|c|c|c|}
\hline No & \multicolumn{1}{|c|}{ Hipotesis Penelitian } & Std.Est & P & Kesimpulan \\
\hline 1 & $\begin{array}{l}\text { Kualitas aparatur daerah berpengaruh positif } \\
\text { dan signifikan terhadap manajemen aset di } \\
\text { Kota Lhokseumawe }\end{array}$ & 0,528 & 0,044 & $\begin{array}{c}\text { Hipotesis } \\
\text { diterima }\end{array}$ \\
\hline 2 & $\begin{array}{l}\text { Regulasi berpengaruh positif dan signifikan } \\
\text { terhadap manajemen aset di Kota } \\
\text { Lhokseumawe }\end{array}$ & 0,514 & 0,048 & $\begin{array}{c}\text { Hipotesis } \\
\text { diterima }\end{array}$ \\
\hline 3 & $\begin{array}{l}\text { Akuntabilitas tidak terhadap manajemen aset } \\
\text { di Kota Lhokseumawe }\end{array}$ & 0,354 & 0,127 & $\begin{array}{c}\text { Hipotesis } \\
\text { ditolak }\end{array}$ \\
\hline 4 & $\begin{array}{l}\text { Sistem informasi akuntasi berpengaruh } \\
\text { positif dan signifikan terhadap manajemen } \\
\text { aset di Kota Lhokseumawe }\end{array}$ & 0,371 & 0,032 & $\begin{array}{c}\text { Hipotesis } \\
\text { diterima }\end{array}$ \\
\hline 5 & $\begin{array}{l}\text { Komitmen organisasi berpengaruh positif } \\
\text { dan signifikan terhadap manajemen aset di } \\
\text { Kota Lhokseumawe }\end{array}$ & 0,973 & $* * *$ & $\begin{array}{c}\text { Hipotesis } \\
\text { diterima }\end{array}$ \\
\hline
\end{tabular}

\section{Implikasi Penelitian}

Implikasi Teoritis

Penelitian ini menghasilkan beberapa implikasi secara teoritis yaitu sebagai berikut: 
1. Hasil penelitian ini menunjukkan bahwa kualitas aparatur daerah berpengaruh positif dan signifikan terhadap manajemen aset si Kota Lhokseumawe. Hasil ini menunjukkan bahwa aparatur daerah pemeritah Kota Lhokseumawe memiliki kualitas dan sumber daya manusia yang mempunyai skil serta kualitas dalam mengelola aset sehingga dapat mengelola manajemen aset tertata baik, terstruktur dan terorganisir. Hasil ini sesuai dengan hasil penelitian-penelitian terdahulu yang mendapatkan bahwa kualitas aparatur daerah berpengaruh positif dan signifikan terhadap manajemen aset.

2. Hasil penelitian ini menunjukkan bahwa regulasi berpengaruh positif dan signifikan terhadap manajemen aset pada pemeritah Kota Lhokseumawe. Hasil ini mengindikasikan pemerintah Kota Lhokseumawe telah mempelajari, mengamati, dan menjalankan regulasi sesuai ketentuan Undang-undang atau Qanun dalam mengelola aset, sehingga data yang berkaitan dengan aset terdaftar dan jelas pada tempatnya. Hasil ini sesuai dengan hasil penelitian-penelitian terdahulu yang menemukan bahwa regulasi berpengaruh positif dan signifikan terhadap manajemen aset.

3. Hasil penelitian ini menunjukkan bahwa akuntabilitas tidak berpengaruh terhadap manajemen aset pada pemeritah kota lhokseumawe. Akuntabilitas tidak berpengaruh terhadap pengelolaan keuangan daerah. Ketidakadanya pengaruh signifikan tersebut dapat dikarenakan berbagai hal diantaranya belum maksimalnya pemanfaatan suatu sistem akuntansi dan sistem anggaran yang dapat menjamin bahwa pengelolaan keuangan daerah dilakukan secara konsisten. Hasil penelitian ini sesuai dan sejalan dengan penelitian sebelumnya serta dapat mendukung dan memperkuat kerangka teoritis dalam pengembangan ilmu manajemen aset.

4. Hasil penelitian ini menunjukkan bahwa sistem informasi akuntansi berpengaruh positif dan signifikan terhadap manajemen aset di Kota Lhokseumawe. Hasil penelitian ini menunjukkan bahwa sistem informasi yang digunakan dalam organisasi memiliki kelebihan seperti kemudahan dalam mendistribusikan program aplikasi, mudah danpraktis karena dapat diakses dari manapun dan kapanpun serta memiliki akses informasi yang lebih cepat. Hasil penelitian ini sesuai dan sejalan dengan penelitian sebelumnya serta dapat mendukung dan memperkuat kerangka teoritis dalam pengembangan ilmu manajemen aset.

5. Hasil penelitian ini menunjukkan bahwa komitmen organisasi berpengaruh positif dan signifikan terhadap manajemen aset di Kota Lhokseumawe. asil penelitian ini menunjukkan bahwa komitmen aparatur mampu mendistribusikan kekuasaannya sehingga dapat diterima dan dipandang sebagai sesuatu yang dapat mendorong untuk terciptanya komitmen yang tinggi dari seluruh pegawai pada instansi yang dipimpinnya. Hasil penelitian ini sesuai dan sejalan dengan penelitian sebelumnya serta dapat mendukung dan memperkuat kerangka teoritis dalam pengembangan ilmu manajemen aset.

\section{Implikasi Manajerial}

1. Hasil penelitian ini menunjukkan bahwa variable kualitas aparatur daerah, regulasi, sistem informasi akuntansi dan komitmen organisasi berpengaruh terhadap manajemen aset. Pengaruh ini membuktikan bahwa kualitas aparatur daerah, regulasi, sistem informasi akuntansi dan komitmen organisas yang harus diperhatikan oleh suatu organisasi.

2. Disisi lain suatu organisasi akuntabilitas juga harus diperhatikan dukarekan pengelolaan keuangan yang baik akan memberikan dampak positif terhadap kinerja pemerintah sehingga akan tercipta pemerintahan yang baik dan tata kelola pemerintahan yang baik.

1. Respon yang masih sedikit rendah dari responden, ditandai dengan adanya beberapa responden yang tidak langsung mengisi kuesioner. Hal ini disebabkan karena responden lebih banyak bertugas di lapangan mendampingi wilayah kerja masing-masing dan ditambah lagi pada saat penyebaran kuesioner beberapa responden sedang mendapatkan tugas mengikuti Diklat Sertifikasi Pendamping Sosial Profesional di BBPKS Regional I Sumatera. Kondisi ini mempengaruhi konsistensi responden dalam memberikan jawaban. 
2. Penelitian ini hanya menggunakan 4 variabel penelitian, yaitu servant leadership, kompetensi komunikasi kepuasan kerja dan kinerja karyawan. Padahal masih banyak variabel lain yang mempengaruhi kinerja karyawan. Oleh karena itu, diharapkan kepada peneliti menggunakan variabel yang lebih banyak untuk memberikan gambaran yang lebih komprehensif.

3. Peneliti merasakan adanya keterbatasan waktu dalam menyelesaikan penelitian ini, satu sisi peneliti ingin menghasilkan penelitian yang memuaskan dan dapat dikembangkan sebagai model untuk penulisan disertasi. Di sisi lain peneliti ingin fokus menyelesaikan perkuliahan secara tepat waktu, begitu juga dengan tenaga dan dukungan referensi yang masih kurang dalam menyelesaikan penelitian ini.

\section{Daftar Referensi}

Allen, NJ., Meyer PJ. And Smith CA., (2003) Commitment to Organizations and Occupations: Extention and Test of a Three-Component Conceptualization, Journal of Applied Psychology, Vol. 78, No. 4.

Arini, Darwanis dan Abdullah (2014) Pengaruh Kompetensi Sumber Daya Manusia, Sistem Informasi, Regulasi, Dan Kompensasi Terhadap Manajemen Aset (Studi Pada Satuan Kerja Badan Kependudukan dan Keluarga Berencana Nasional di Indonesia). Jurnal Magister Akuntansi Pascasarjana Universitas Syiah Kuala

Azhar (2017) Pengaruh Kualitas Aparatur Daerah dan Regulasi terhadap Manajemen Aset pada Pemerintah Kota Banda Aceh. Jurnal Penelitian Ekonomi Akuntansi. Vol. 1, No. 1.

Azhar, Iqlima., Darwanis dan Abdullah, Syukriy. (2013) "Pengaruh Kualitas Aparatur Daerah, Regulasi, dan Sistem Informasi Terhadap Manajemen Aset”, Jurnal Akuntansi. Pasca Sarjana Universitas Syiah Kuala. Vol. 2, No. 1.

Bastian, Indra. (2014). Akuntansi Sektor Publik. Jakarta: Erlangga.

Bello, Asnawi dan Wijaya. (2018). Analisis Faktor-Faktor Yang Mempengaruhi Kualitas Pengelolaan Barang Milik Daerah Pada Opd Di Lingkungan Pemerintah Kabupaten Waropen Dengan Komitmen Pimpinan Sebagai Variabel Moderating. Jurnal Akuntansi, Audit \& Aset. Volume 1, Nomor 2

Darise, Nurlan. (2009). Pengelolaan Keuangan Daerah. Edisi 2. Jakarta: Indeks

Dyne, L, graham J.W. (2005) Organizational Citizenship Behavior, Construct Redefinition Measurement and Validation, Academic Management Journal

Griffin, Ricky. (2013). Manajemen. Edisi 7 Jilid 1. Jakarta: Erlangga. 
Halim. (2012). "Pengaruh Komitmen Organisasi dan Peranan Kepemimpinan dalam Meningkatkan Pengelolaan Keangan Daerah pada Dinas Pendapatan, Pengelolaan Keuangan dan Aset Kabupaten Banggai Kepulauan", Jurnal Academica Fisip Untad, Vol.04. No.01.

Haider, Abrar. (2011). Information and Operational Technologies Governance Framework for Engineering Asset Management in Mathew, Joseph, Lin Ma, Andy Tan, Margot Weijnen, Jay Lee (2011) Engineering Asset Management and Infrastructure Sustainability: 299-313 Springer-Verlag London Limited.

Handoko (2011) Manajemen. Edisi kedua. Yogyakarta: BPFE

Hasibuan, Malayu. (2017). Manajemen Sumber Daya Manusia. Jakarta: Bumi Aksara.

Ishak, M. (2011). Akuntansi dan Aspek-Aspek perilaku. Paper yang disampaikan pada saat melakukan pembimbingan teknis atas pengelolaan keuangan daerah Pemerintah Kota Magelang.

Kadir, A.,(2015). Pengenalan Sistem Informasi. Yogyakarta: ANDI.

Kurniawan, Wawan. (2015). Peraturan Perundang-undangan. Jakarta: Azka Press.

Kreitner, Robert dan Angelo Kinicki. (2014). Perilaku Organisasi. Edisi 9. Buku 1. Jakarta: Salemba Empat.

LAN. (2007). Diklat Teknis Manajemen Aset Daerah. Modul I: Dasar-dasar Manajemen Aset/BarangMilik Daerah.

Luthans, Fred. (2016). Perilaku Organisasi. (Alih Bahasa V.A Yuwono, dkk).Edisi Bahasa Indonesia. Yogyakarta: ANDI.

Mahmudi. (2016). Manajemen Keuangan Daerah. Jakarta: Erlangga.

Mainar, Darwanis dan Abdullah (2017) Pengaruh Sistem Pengendalian Intern, Pemahaman Regulasi, Dan Sistem Informasi Terhadap Manajemen Aset (Studi pada SKPK di Kabupaten Aceh Jaya). Jurnal Akuntasi Pascasarjana Universitas Syiah Kuala

Mardiasmo. (2018). Akuntansi SektorPublik. Penerbit Andi. Yogyakarta.

Mathis R.L dan Jackson J.H. (2012). Manajemen Sumber Daya Manusia: Diterjemahkan oleh Jimmy Sadeli dan Bayu Prawira Hie. Edisi kelima. Salemba Empat, Jakarta.

Miner. (2013). Organizational Behavior, Performance \& Productivity, State University, New York, at Buffallo.

Muljo, Kurniawati dan Pahala (2014) Pengaruh Akuntabilitas Dan Transparansi Terhadap Pengelolaan Anggaran. Jurnal Binus Business Review Vol. 5 No. 2. 